\title{
EFFECTS OF TAI CHI ON COGNITIVE FUNCTIONS AND MOTOR LEARNING IN PERSONS WITH MULTIPLE SCLEROSIS
}

\author{
Ilona Tubytė, Rima Solianik, Diana Karanauskienė \\ Lithuanian Sports University
}

\begin{abstract}
Research background. The existing evidence supports the effectiveness of Tai Chi for persons with multiple sclerosis (MS) in various domains including depression, coordination, balance, and fatigue. However, we are not aware of any previous studies of the effects of Tai Chi on cognition and motor skill learning in persons with MS.

The aim of this study was to determine the effects of Tai Chi on cognitive functions and motor learning in persons with multiple sclerosis.

Methods. The study included 16 participants with MS. They were randomly assigned to intervention $(\mathrm{n}=8)$ and control $(\mathrm{n}=8)$ groups. The intervention consisted of a 60-min Tai Chi exercise program twice a week, for 8 weeks, while the control group was instructed to maintain their routine daily activities. Cognitive functions and learning of accurate movements were evaluated before and after the 8 weeks in each group.

Results. Tai Chi exercise program improved $(\mathrm{p}<0.05)$ working memory and attention switching, whereas no changes were observed in short-term memory and attention stability in persons with multiple sclerosis. Furthermore, Tai Chi facilitated $(p<0.05)$ motor learning when compared with the control group.

Conclusions. Tai Chi can be used as an effective intervention to improve cognitive functions, such as working memory and predictable attention switching, and motor skill learning in persons with multiple sclerosis.
\end{abstract}

Keywords: working memory, attention switching, meditation, motor skills.

\section{INTRODUCTION}

Multiple sclerosis (MS) is a chronic inflammatory disease of the central nervous system leading to different degrees of physical or cognitive disability as well as neurological defects (Ghasemi et al., 2017; Rosenberg et al., 2017). Cognitive impairment affects approximately $40-70 \%$ of individuals with MS (Rosenberg et al., 2017). It is well established that cognitive processes contribute to motor skill learning (Seidler, Anguera, 2012), and that motor learning is impaired in MS (Leocani et al., 2007; Tacchino et al., 2014). These impairments reduce physical independence and overall quality of life (Rosenberg et al., 2017).

Though it is well established that Tai Chi improves balance, coordination, and reduces depression and fatigue (Burchka et al., 2014), we are not aware of any previous studies of the effect of Tai Chi on cognitive function and motor learning in individuals with MS. In general, it is well established that Tai Chi is an aerobic 
exercise and provides benefits for cognitive function (Zheng et al., 2017; Sungkarat et al., 2018). It increases plasma brain-derived neurotrophic factor (BDNF) level (Sungkarat et al., 2018), which affects neuroplasticity by facilitating long-term potentiation, a long-lasting increase in the strength of connections between neurons that are repeatedly activated together and by promoting dendritic growth and remodelling. There is evidence that these changes affect not only cognition, but also motor learning (Mang et al., 2013; Taubert et al., 2015). Thus it can be expected that Tai Chi would improve cognition and motor learning for individuals with MS.

The aim of this study was to estimate the effect of Tai Chi on cognitive functions and motor learning in persons with multiple sclerosis.

\section{RESEARCH METHODS}

Participants. Twenty six volunteers with MS were assessed for eligibility. The criteria for inclusion were (1) relapsing-remitting MS; (2) age 18-60 years; (3) ability to walk without a walking aid; (4) a Mini Mental State Evaluation (MMSE) score $\geq 21$; and (4) an Expanded Disability Status Scale (EDSS) score from 2.0 to 5.5. Exclusion criteria were (1) acute and severe recurrences of disease; (2) other neurologic disorders (e.g., Parkinson's disease, amyotrophic lateral sclerosis); (3) involvement in any other exercise program; (4) refusing Tai Chi sessions during the study. In total, 16 volunteers met the inclusion criteria and agreed to participate in this study. Their characteristics are presented in Table 1. All participants were with normal or corrected-to-normal vision. Written informed consent was obtained from all participants. All procedures were approved by the Lithuanian Sports University Bioethics Committee (No. 17/12) and were conducted according to the guidelines of the Declaration of Helsinki.

Table 1. Characteristics of the participants

\begin{tabular}{|l|c|c|}
\hline Parameter & Control group (n= 8) & Experimental group (n= 8) \\
\hline Age (yrs) & $44.5(5.3)$ & $42.3(5.9)$ \\
\hline Weight (kg) & $68.8(15.3)$ & $76.6(20.0)$ \\
\hline Height (cm) & $165.5(10.0)$ & $173.8(11.7)$ \\
\hline Gender (F:M) (n) & $6: 2$ & $4: 4$ \\
\hline Disease duration (yrs) & $10.9(7.1)$ & $9.4(5.1)$ \\
\hline EDSS & $4.3(1.3)$ & $3.6(0.6)$ \\
\hline Assistive devices & 5 & 8 \\
Never use (n) & 3 & 0 \\
Sometimes use (n) & 0 & 0 \\
Always use (n) & $28.9(1.6)$ & $29.1(1.5)$ \\
\hline MMSE & & \\
\hline
\end{tabular}

Notes. Data are presented as mean (standard deviation). F, female; M, male; EDSS, Expanded Disability Status Scale; MMSE, Mini Mental State Evaluation. 
Procedures. One week before the experiment, the participants were familiarized with the experimental procedures used for cognitive testing and motor learning evaluation. Before each laboratory visit, participants were instructed to sleep for $\geq 7 \mathrm{~h}$ and to refrain from engaging in vigorous physical activity for $\geq 48$ hours, as well as ingesting alcohol for $\geq 24 \mathrm{~h}$, caffeine and eating for $\geq 2 \mathrm{~h}$.

Each participant was tested at approximately the same time of day, to attenuate any diurnal fluctuations in motor and cognitive processes. On arrival at the laboratory, the participants were seated at a table in a well-lit room, and cognitive testing was performed. Subsequently, participants completed the pursuit rotor test containing a single 15 -second tracking block.

Thereafter, the participants were randomly assigned to either the experimental $(n=8)$ or the control $(n=8)$ group. Participants in the experimental group attended a 60-minute Tai Chi practice session twice a week for 8 weeks. The session consisted of a 10-minute warm-up and a 10-minute cool-down period. The selected version of Tai Chi consisted of six movements as described elsewhere ( $\mathrm{Li}$ et al., 2012). During the exercise program, the participants were instructed to track the intensity of the exercise intervention, and to exercise $\leq 13$ (somewhat hard) on the 6-20 Borg scale. Experienced Tai Chi instructor was selected by investigators to teach classes. Meanwhile, participants in the control group were instructed to maintain their routine daily activities.

After 8 weeks, cognitive assessment was repeated and motor learning was evaluated. In order to evaluate learning, the participants performed four 15-second tracking blocks with 30 -second of rest between blocks.

Experimental measurements. Cognitive performance. Cognitive functions were assessed using the computerized neuropsychological assessment battery (Effecton Inc., Russia). All tests were performed in a quiet and well-lit room with a laptop screen $\sim 40 \mathrm{~cm}$ in front of the participant. The test battery included the following tests in a randomized order: the forward digit-span test was used to evaluate short term memory, the free recall test was used to evaluate working memory, the visual search test was used to evaluate attention stability, and the complex visual search and predictable task switching test were used to evaluate attention switching. These tests have been described in more detail elsewhere (Solianik et al., 2016).

Motor performance. Motor function was assessed using the Psychology Experiment Building Language (PEBL) test battery (Version 0.14). The pursuit rotor test was used to evaluate psychomotor function (Solianik, Sujeta, 2018). During this test, participants were instructed to move the computer mouse so that the mouse cursor tracked a smoothly moving target as it moved across the screen in a 
circular pattern. The time on target and error, the difference in pixels between the cursor and target, were recorded.

Statistical analysis. Statistical analysis was carried out using SPSS v.21.0 (IBM Corp., USA). Data are presented as means and standard deviations. The data were tested for normal distribution using the Kolmogorov-Smirnov test, and all data were found to be normally distributed. To assess the effects of time on measured variables, the parametric paired sample $t$ tests were performed, and to compare the data between the control and the experimental groups, unpaired sample t-tests were performed. The level of significance was set at $\mathrm{p}<0.05$.

\section{RESEARCH RESULTS}

The data for cognitive performance measurements are reported in Table 2. No significant differences were observed between cognitive performance indicators in the control and the experimental groups at baseline. The Tai Chi exercise program significantly increased $(p<0.05)$ the percentage of correct answers in the Free Recall Test and decreased $(p<0.05)$ test time duration in the Complex Visual Search and Task Switching Test, whereas performance on other tests was not affected. As expected, no changes were observed in the control group.

Table 2. Effect of Tai Chi on cognitive functions

\begin{tabular}{|l|c|c|c|c|}
\hline \multirow{2}{*}{ Parameter } & \multicolumn{1}{|c|}{ Control group } & \multicolumn{1}{c|}{ Experimental group } \\
\cline { 2 - 5 } & Before & After & Before & After \\
\hline Forward digit-span test & $215.6(33.1)$ & $221.4(33.0)$ & $208.5(48.7)$ & $217.4(43.8)$ \\
\hline Test time (s) & $5.50(0.78)$ & $6.01(0.73)$ & $5.53(0.93)$ & $6.20(0.82)$ \\
\hline Mean digits identified (n) & $178.0(36.3)$ & $210.1(41.0)$ & $181.0(73.4)$ & $222.3(86.4)$ \\
\hline Free recall test & $45.0(12.8)$ & $53.1(8.0)$ & $44.1(15.5)$ & $54.4(17.0)^{*}$ \\
\hline Test time (s) & $50.1(11.2)$ & $47.0(9.41)$ & $60.3(23.3)$ & $60.8(29.8)$ \\
\hline Correct answers (\%) & $266.4(33.3)$ & $248.4(47.7)$ & $270.0(38.5)$ & $252.3(46.8)^{*}$ \\
\hline Visual search test & $13.3(12.0)$ & $10.5(10.9)$ & $13.4(17.8)$ & $10.8(17.9)$ \\
\hline Mean test time (s)
\end{tabular}

Notes. Data are presented as mean (standard deviation).

$*-\mathrm{p}<0.05$ compared with values before the experiment.

The data on the changes in movement performance indicators during motor learning are presented in the Figure. No differences were observed between Block 0 and Block 1 in both groups. As compared to Block 1, both groups significantly 
increased $(\mathrm{p}<0.05)$ time on target, whereas only Tai Chi exercise program significantly decreased $(\mathrm{p}<0.05)$ errors in the last block. Error rate during last two blocks was lower $(\mathrm{p}<0.05)$ in the experimental group compared to the control group.
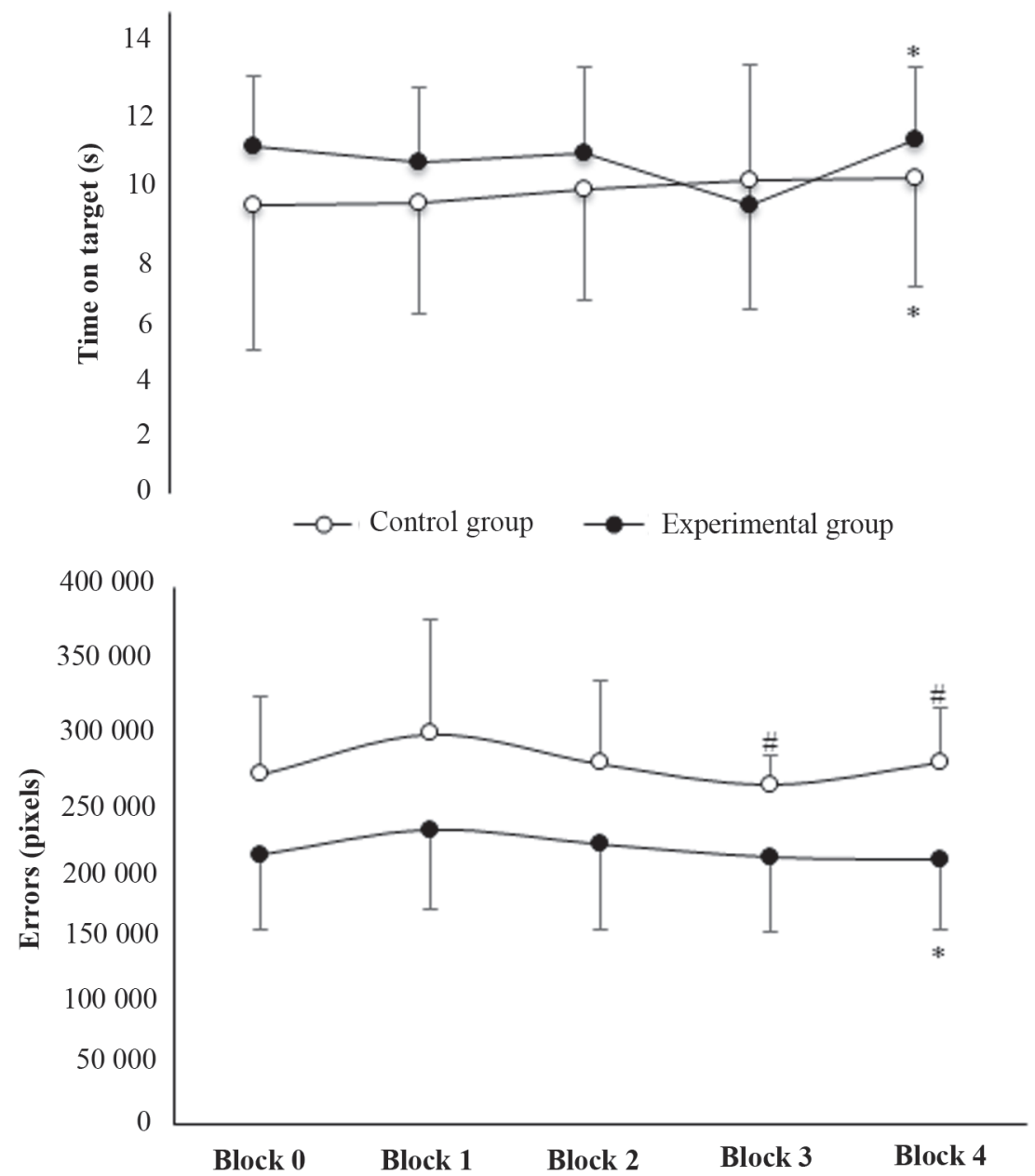

Notes. Data are presented as mean (standard deviation). ${ }^{*}-p<0.05$ compared with Block $1 ; \#-p<0.05$ compared with the experimental group.

Figure. Effect of Tai Chi on motor learning

\section{DISCUSSION}

The aim of the present study was to determine the effect of Tai Chi on cognitive functions and motor learning in persons with multiple sclerosis. We observed that 
8-week Tai Chi exercise program improved cognitive functions, such as working memory and attention switching, and facilitated motor learning. To our knowledge, this is the first study to examine behavioural changes after Tai Chi exercise program in persons with MS.

The effect of Tai Chi on cognitive functions. Consistent with previous studies (Zheng et al., 2017; Sungkarat et al., 2018), in our study, Tai Chi exercise program improved cognition in individuals with MS. We observed complex effects on different cognitive functions; working memory and attention switching improved, but short-term memory, visual recognition memory and attention stability were not affected. $B D N F$ levels were lower in individuals with MS and correlated with increased time of execution in a divided attention and visual scanning task (Patanella et al., 2010). S. Sungkarat et al. (2018) observed that BDNF levels increased after Tai chi, thus it can be expected that this increase resulted in improved attention switching. Furthermore, consistent with our results, it was established that more consistent positive effects of Tai Chi were found on memory function, especially working memory (Wu et al., 2013). It is noteworthy that Tai Chi is a common type of aerobic exercise (Zheng et al., 2017) and previous studies in older adults concluded that the largest effects on cognition occur in the executive control domain, including functions such as planning, scheduling, working memory, and multitasking (Colcombe, Kramer, 2003; Mang et al., 2013).

The effect of Tai Chi on motor learning. In accordance with our expectations, we have observed that Tai Chi exercise program facilitated motor learning in individuals with MS. Nevertheless, we are not aware of any previous studies of the effect of Tai Chi on motor learning. It is worth mentioning that Tai Chi is an aerobic exercise (Zheng et al., 2017) and previous studies have observed that long-term aerobic exercise can improve motor learning (Quaney et al., 2009; Duchesne et al., 2016). It is well established that motor learning process is mediated by neuroplasticity, and BDNF has emerged as a key facilitator of neuroplasticity (Mang et al., 2013; Taubert et al., 2015). Evidence demonstrates that Tai Chi increases BDNF level (Sungkarat et al., 2018), and consequently enhances learning processes (Mang et al., 2013). Furthermore, the cognitive processes also contribute to motor skill learning (Seidler, Anguera, 2012). It is suggested that individual differences in working memory capacity can predict the rate of motor learning (Seidler, Anguera, 2012; Buszard et al., 2017). Thus, in the current study observed improved working memory is consistent with observed improvement in learning.

Future perspectives. Future studies should examine the underlying mechanisms of the observed response, and define molecular signalling pathways respon- 
se to Tai Chi exercise program in individuals with MS. In addition, considerable knowledge gaps remain regarding the optimal intensity, duration and frequency of exercise to promote cognition and motor learning (Taubert et al., 2015). Finally, there is evidence that not only long-term aerobic exercise affects behaviour, but also acute bout of aerobic exercise can improve cognition and motor learning (Mang et al., 2013). Since Tai Chi is an aerobic exercise (Zheng et al., 2017), future research should examine the effect of an acute bout of such exercise and to indicate whether individuals with MS are responsive or not to the immediate effects of Tai Chi on cognition and motor learning.

\section{CONCLUSIONS}

Tai Chi can be used as an effective intervention to improve cognitive functions, such as working memory and attention switching, and motor skill learning in persons with multiple sclerosis.

Acknowledgements. We would like to thank the volunteers for participating in this study, the honorary president of Lithuanian Wushu Federation and Lithuanian Tai Chi Chuan Association, the president of Lithuanian Tai Chi Chuan Association, and MS community leaders for cooperation, assistance and support.

\section{REFERENCES}

Burschka, J. M., Keune, P. M., Oy, U. H., Oschmann, P., Kuhn, P. (2014). Mindfulness - based interventions in multiple sclerosis: Beneficial effects of Tai Chi on balance, coordination, fatigue and depression. BMC Neurology, 14, 165.

Buszard, T., Farrow, D., Verswijveren, S. J. J. M. et al. (2017). Working memory capacity limits motor learning when implementing multiple instructions. Frontiers in Psychology, 8, 1350.

Colcombe, S., Kramer, A. F. (2003). Fitness effects on the cognitive function of older adults: A meta-analytic study. Psychological Science, 14 (2), 125-130.

Duchesne, C., Gheysen, F., Bore, A. et al. (2016). Influence of aerobic exercise training on the neural correlates of motor learning in Parkinson's disease individuals. NeuroImage: Clinical, 12, 559-569.

Ghasemi, N., Razavi, S., Nikzad, E. (2017). Multiple sclerosis: Pathogenesis, symptoms, diagnoses and cellbased therapy. Cell Journal, 19 (1), 1-10.

Leocani, L., Comi, E., Annovazzi, P. et al. (2007). Impaired short-term motor learning in multiple sclerosis: Evidence from virtual reality. Neurorehabilitation and Neural Repair, 21 (3), 273-278.

Li, F., Harmer, P., Fitzgerald, K. et al. (2012). Tai Chi and postural stability in patients with Parkinson's disease. New England Journal of Medicine, 366 (6), 511-519.

Mang, C. S., Campbell, K. L., Ross, C. J. D., Boyd, L. A. (2013). Promoting neuroplasticity for motor rehabilitation after stroke: Considering the effects of aerobic exercise and genetic variation on brain-derived neurotrophic factor. Physical Therapy, 93 (12), 1707-1716.

Patanella, A. K., Zinno, M., Quaranta, D. et al. (2010). Correlations between peripheral blood mononuclear cell production of BDNF, TNF-alpha, IL-6, IL-10 and cognitive performances in multiple sclerosis patients. Journal of Neuroscience Research, 88 (5), 1106-1112.

Quaney, B. M., Boyd, L. A., McDowd, J. M. et al. (2009). Aerobic exercise improves cognition and motor function post stroke. Neurorehabilitation and Neural Repair, 23 (9), 879-885. 
Ilona Tubytė, Rima Solianik, Diana Karanauskienė

Rosenberg, A. J., Wee, S. O., Shroeder, E. C. et al. (2017). The effects of acute aerobic exercise on cerebral blood flow and cognition in persons with multiple sclerosis. The FASEB Journal, 31 (Suppl. 1), 842.4842.4. Retriewed from https://www.fasebj.org/action/showCitFormats?doi=10.1096\%2Ffasebj.31.1_ supplement.842.4

Seidler, R. D., Bo, J., Anguera, J. A. (2012). Neurocognitive contributions to motor skill learning: the role of working memory. Journal of Motor Behavior, 44 (6), 445-453.

Solianik, R., Brazaitis, M., Skurvydas, A. (2016). Sex-related differences in attention and memory. Medicina, 52 (6), 372-377.

Solianik, R., Sujeta, A. (2018). Two-day fasting evokes stress, but does not affect mood, brain activity, cognitive, psychomotor, and motor performance in overweight women. Behavioural Brain Research, 338, 166-172.

Sungkarat, S., Boripuntakul, S., Kumfu, S., Lord, S. R., Chattipakorn, N. (2018). Tai Chi improves cognition and plasma BDNF in older adults with mild cognitive impairment: A randomized controlled trial. Neurorehabilitation and Neural Repair, 32 (2), 142-149.

Tacchino, A., Bove, M., Roccatagliata, L. et al. (2014). Selective impairments of motor sequence learning in multiple sclerosis patients with minimal disability. Brain Research, 1585, 91-98.

Taubert, M., Villringer, A., Lehmann, N. (2015). Endurance exercise as an "endogenous" neuro-enhancement strategy to facilitate motor learning. Frontiers in Human Neuroscience, 9, 692.

Wu, Y., Wang, Y., Burgess, E. O., Wu, J. (2013). The effects of Tai Chi exercise on cognitive function in older adults: A meta-analysis. Journal of Sport and Health Science, 2 (4), 193-203.

Zheng, W., Xiang, Y. Q., Ungvari, G. S. et al. (2017). Tai Chi for mild cognitive impairment: A systematic review. Psychogeriatrics, 17 (6), 514-516.

\section{TAI ČI PRATIMŲ POVEIKIS ASMENŲ, SERGANČIŲ IŠSĖTINE SKLEROZE, PAŽINTINĖMS FUNKCIJOMS IR JUDESIŲ MOKYMUISI}

\section{Ilona Tubytė, Rima Solianik, Diana Karanauskienė \\ Lietuvos sporto universitetas}

\section{SANTRAUKA}

Tyrimo pagrindimas. Yra įrodymų, kad Tai či pratimai gali pagerinti asmenų, sergančių išsètine skleroze (IS), pusiausvyrą ir koordinaciją, sumažinti jų nuovargị ir depresiją. Visgi nèra ištirta, kaip Tai či paveiktų sergančiujų išsètine skleroze pažintines funkcijas ir judesių mokymąsi.

Tikslas - nustatyti Tai či pratimų poveikị asmenų, sergančių išsėtine skleroze, pažintinèms funkcijoms ir judesių mokymuisi.

Metodai. Buvo tiriama 16 asmenų, sergančiu IS, kurie atsitiktine tvarka suskirstyti ị vieną iš dviejų grupių: tiriamają $(n=8)$ arba kontrolinę $(n=8)$. Tiriamoji grupė lankė 8 savaičių trukmės Tai či pratybas. Jos vyko du kartus per savaitę po 60 min. Tuo tarpu kontrolinès grupės buvo prašoma laikytis ịprastinès kasdienės rutinos. Prieš pratybas ir po 8 savaičių buvo įvertintos abiejų grupių pažintinès funkcijos ir tikslių judesių mokymasis. 
Rezultatai. Tai či pratimų programa pagerino sergančiųų išsètine skleroze $(\mathrm{p}<0,05)$ darbinę atmintị ir dėmesio paskirstymą, bet neturejjo įtakos jų trumpalaikei atminčiai, dėmesio stabilumui. Be to, lyginant su kontroline grupe, Tai či pratimų programa pagerino $(\mathrm{p}<0,05)$ judesių mokymąsi.

Išvados. Tai či pratimai gali būti naudojami kaip efektyvi priemonè, gerinanti asmenų, sergančių išsètine skleroze, judesių mokymąsi ir pažintines funkcijas, tokias kaip darbinè atmintis ir dèmesio paskirstymas.

Raktažodžiai: darbinè atmintis, dėmesio paskirstymas, meditacija, motorinis igūdis. 